\title{
KANDUNGAN LOGAM DASAR DI DALAM ENDAPAN LETAKAN PANTAI DAN \\ LEPAS PANTAI PERAIRAN PAMEUNGPEUK, GARUT, JAWA BARAT. INDIKASI ADANYA MINERALISASI HIDROTHERMAL DI DARAT
}

\author{
Oleh: \\ A. Setyanto dan D. Setiady \\ Puslitbang Geologi Kelepas pantaian
}

SARI

Sebaran hasil analisis geokimia untuk logam dasar baik contoh-contoh pantai maupun lepas pantai memperlihatkan adanya pengelompokan kandungan baik untuk unsur-unsur Tembaga $(\mathrm{Cu})$, Timbal (Pb), dan seng ( $\mathrm{Zn})$ ataupun logam emas (Au) dan perak (Ag).

Perbedaan lingkungan pengendapan di pantai dan lepas pantai berpengaruh kepada kandungan logam dasar. Di lingkungan pantai kandungan unsur logam dasar yaitu $\mathrm{Cu}, \mathrm{Pb}$ dan $\mathrm{Zn}$ rata-rata lebih tinggi dari pada lingkungan pengendapan lepas pantai. Kandungan emas (Au) dan perak (Ag) dipantai juga lebih tinggi di bandingkan dengan di lepas pantai.

Sebaran logam dasar dari timur ke barat memperlihatkan variasi kandungan yang juga berbeda antara logam dasar $\mathrm{P}, \mathrm{Cu}$ dan kandungan $\mathrm{Zn}$. Kandungan Zn selalu lebih tinggi daripada kandungan $\mathrm{Pb}$ dan $\mathrm{Cu}$. Variasi ini juga terlihat berbeda antara lingkungan pantai dengan variasi yang jauh lebih mencolok/variatif pada lingkungan lepas pantai.

Kata kunci : lingkungan pengendapan, sebaran logam dasar

\section{ABSTRACT}

The distribution of geochemical analysis result for base metal offshore and onshore samples shows the composition cluster between $\mathrm{Cu}, \mathrm{Pb}, \mathrm{Zn}$ elements and $\mathrm{Au}$, Ag elements.

Differences between onshore and offshore depositional environment influence the base metal content. Base metal ( $\mathrm{Cu}, \mathrm{Pb}$ and $\mathrm{Zn}$ ) content on the shore environment is higher than that in the offshore environment. Gold $(A u)$ and silver $(A g)$ content on the shore environment is higher than that in the offshore environment.

The base metal distribution from east to west shows the base metal variation between $\mathrm{Pb}$ and $\mathrm{Cu}$ base metal content and $\mathrm{Zn}$ base metal content. Zn base metal content is always higher than $\mathrm{Pb}$ and $\mathrm{Cu}$ base metal content. This variation is also different between coastal and onshore environments. There are higher variation in offshore than that in the onshore environment

Key Words : depositional environment, base metal distribution

\section{PENDAHULUAN}

Endapan logam dasar di pantai dan lepas pantai pada umumnya terjadi akibat proses pelapukan (weathering) dan transportasi yang terdapat sebagai endapan letakan (placer) yang dihasilkan dari cebakan hidrothermal, yang berkaitan dengan batuan intrusi.

Daerah telitian secara administratif berada di sekitar Kecamatan Pameungpeuk, Kecamatan Cikelet, Kecamatan Pakenjeng dan Kecamatan Bungbulang, Kabupaten Garut, Propinsi Jawa Barat. Daerah tersebut merupakan perairan terbuka yang berhadapan langsung dengan Samudera Indonesia. Secara geografis berada di dalam koordinat $107^{\circ} 26^{\prime}-107^{\circ} 45^{\prime}$ BT dan $7^{\circ} 28^{\prime}$ - $7^{\circ} 44^{\prime}$ LS (Gambar. 1) dengan luas daerah selidikan $\pm 309.872 \mathrm{~km}^{2}$.

\section{METODE PENELITIAN}

Metoda pemboran tangan dilakukan sebanyak 13 lokasi (BPM), untuk mengetahui kedalaman dari sedimen dalam hal ini pasir sampai menembus batuan dasar. Percontoh pantai di permukaan sebanyak 26 contoh (PPM) yang berurutan dari arah timur daerah telitian sampai ke barat. Sedangkan sebanyak 53 percontoh lepas pantai diambil dengan menggunakan pemercontoh comot.(Gambar 2) 
Pengambilan percontoh untuk analisa unsurunsur emas (Au), perak (Ag), tembaga (Cu), timbal $(\mathrm{Pb})$ dan seng ( $\mathrm{Zn})$ di ambil dari contohcontoh paras pantai dan litologi paling atas pada percontoh bor tangan (BPM) dan percontoh permukaan (PPM). Sedangkan untuk pengambilan percontoh di lepas pantai diambil secara acak bersistem (systematic random sampling) pada lokasi-lokasi yang representatif dengan mempertimbangkan faktor-faktor oseanografi (arah gelombang, arus sepanjang pantai, pasang-surut) dan posisi muara-muara sungai sebagai pemasok sedimen asal darat.

\section{HASIL PENELITIAN}

Kemungkinan batuan dasar dari endapan logam dasar di pantai dan lepas pantai adalah batuan- batuan yang terdapat disekitar Perairan Pameungpeuk. Menurut Alzwar, 1992, uruturutan formasi batuan di daerah telitian terdiri dari:

Formasi Bentang, merupakan batuan sedimen, batupasir tuf, tuf batuapung, batulempung, konglomerat dan lignit. Bagian bawah terdiri dari konglomerat, batupasir tuf, tuf batuapung bersisipan lempung, batulanau dan lignit, bagian atas terdiri dari batupasir tuf dan tuf kaca halus berbatu apung. terdapat dalam batupasir tuf.

Formasi Jampang, merupakan batuan gunungapi. Lava bersusunan andesit yang menunjukkan kekar dan breksi andesit yang mengandung hornblende, sisipan tuf hablur. Di daerah Singajaya dijumpai batugamping yang mengandung foraminifera besar.

Breksi tufaan, breksi, tuf, dan batupasir. Breksi mengandung komponen andesit dengan masadasar tuf berbatuapung.

Batuan Gunungapi tua tak terturaikan, tuf, breksi tuf dan lava. Tuf terdiri dari dari tuf hablur yang halus, tersilikakan dan terpropilitkan secara setempat. Breksi tuf berkomponen andesit dengan masadasar tuf batuapung. Lava bersusunan andesit piroksen dan basal, menunjukkan kekar lembar, kekar meniang dan struktur aliran. Singkapannya banyak dijumpai di selatan G. Cikuray. Sumber asal batuan terbentuk melalui erupsi celah dan diduga berumur Plio-Plistosen.

Batuan terobosan Andesit, andesit hornblende dan andesit piroksen, batuan tersebut bertekstur porfiri, fenokris berupa plagioklas jenis oligoklas - andesine, hornblende, piroksen, dengan masa dasar mikrolet felspar dan mineral mafik, batuan ini menerobos batuan yang berumur Mio-Pliosen dan diduga berumur Pliosen.

Sebaran hasil analisis geokimia baik contohcontoh pantai maupun lepas pantai (Tabel 1, 2 dan 3), memperlihatkan adanya pengelompokan kandungan baik untuk unsur-unsur logam dasar ( $\mathrm{Cu}, \mathrm{Pb}, \mathrm{Zn})$ ataupun logam emas (Au) dan perak (Ag). Zn mempunyai kandungan rata-rata jauh di atas $\mathrm{Cu}$ dan $\mathrm{Pb}$ baik di pantai maupun lepas pantai (Lepas pantai) (Gambar 3 dan 4). Sedangkan kandungan rata-rata $\mathrm{Cu}$ dan $\mathrm{Pb}$ hampir sama baik di pantai maupun lepas pantai. Perbedaan lingkungan pengendapanpun ternyata membedakan kandungan; dalam hal ini di lingkungan pantai untuk ketiga unsur utama tersebut kandungan rata-rata lebih tinggi dari pada lingkungan pengendapan lepas pantai. Kandungan emas ( $\mathrm{Au}$ ) dan $(\mathrm{Ag})$ terlihat sangat jauh berbeda, namun untuk kedua lingkungan pengendapan di pantai dan lepas pantai, kandungan rata-ratanya tidak banyak perbedaan kecuali pada titik pengamatan pantai PPM-8 jumlah nya mencapai 65 ppb, jauh di atas kandungan emas di tempat lainnya (gambar 5 dan gambar 6). Gambar 5 dan 6 yang memperlihatkan sebaran emas dan perak secara komposit lebih merupakan ilustrasi kualitatif untuk menggambarkan pola perubahan kandungan masing-masing dengan tidak mempunyai hubungan kandungan yang dekat atau seragam antara kandungan emas dan perak. Ini disebabkan jumlah emas yang sangat kecil bersatuan ppb dibandingkan kandungan perak yang bersatuan ppm (1000 X ppb).

\section{DISKUSI}

Urut-urutan kejadian konsentrasi oksida atau sulfida unsur-unsur logam dasar, emas dan perak dalam sedimen dapat dirunut mulai dari provenance batuan daerah telitian, baik untuk lingkungan darat maupun perairanya; dengan memasukkan mekanisme sedimentasi dan media pembawanya (sungai dan perairan pantai). Di daerah telitian terdapat tiga formasi yaitu Formasi Jampang (Miosen Awal) yang didominasi oleh breksi volkanik bersifat andesitik sedikit basaltik, Formasi Bentang (Pliosen), didominasi oleh batupasir pantai gampingan / kalkarenit dan Aluvium (Resen) (Alzwar, 1992). Dari ketiga sumber sedimen tersebut Aluvium merupakan sumber terbesar untuk lokasi-lokasi contoh.

Unsur logam dasar $\mathrm{Pb}$ dalam sedimen aluvial umumnya merupakan senyawa mineral sulfida yang dimulai dari pembentukan Galena (PbS) secara hidrotermal (Whitten, \& Brooks, 1982). 
Kemudian dalam perkembangan berikutnya pada tahap alterasi terjadi oksidasi dan replacement terhadap zona endapan timah hitam. Oksidasi sangat mungkin terjadi di daerah telitian yang beriklim tropis dengan intensitas sinar matahari sepanjang tahun yang cukup tinggi. Pada tahap ini dapat terbentuk Serusit $\left(\mathrm{PbCO}_{3}\right)$ atau Piromorfit $\left((\mathrm{PbCl}) \mathrm{Pb}_{4}\left(\mathrm{PO}_{4}\right)_{3}\right)$ atau Wulfenit $\left(\mathrm{PbMoO}_{4}\right)$. Dengan mempertimbangkan sumber batuan utama Formasi Jampang yang berumur N4-N6 (Miosen Awal) sebagai satu-satunya yang terjadi secara volkanis maka dapat diinterpretasikan sumber unsur $\mathrm{Pb}$ pada contoh adalah batuan Serusit. Sedangkan batuan terobosan dan breksi umur nya relatif masih muda sebagai sumber unsur $\mathrm{Pb}$.

Unsur logam dasar $\mathrm{Cu}$ dalam sedimen aluvial juga berasal dari proses yang sama dengan unsur utama lainnya, yang mana pertama kali terbentuk dapat berupa bijih logam $\mathrm{Cu}$ (copper) dan Kalkopirit $\left(\mathrm{CuFeS}_{2}\right)$ yang terjadi secara hidrotermal atau metasomatik, Kovelit (CuS) terjadi secara pengayaan sekunder, dan Tetrahedrit $\left((\mathrm{Cu}, \mathrm{Fe})_{12} \mathrm{Sb}_{4} \mathrm{~S}_{13)}\right.$ terjadi secara hidrotermal. Pelapukan terhadap batuan beragregat copper, pada tahap selanjutnya, menghasilkan mineral Kuprit $\left(\mathrm{Cu}_{2} \mathrm{O}\right)$, Malakhit $\left(\mathrm{Cu}_{2} \mathrm{CO}_{3}(\mathrm{OH})\right)$ yang juga dapat berfungsi sebagai material semen pada batupasir. Dari formasi batuan yang ada maka genesa Formasi Jampang merupakan kejadian volkanisme yang menghasilkan bijih ataupun unsur logam dasar $\mathrm{Cu}$ terobosan batuan beku dominan andesitik. Sehingga kadarnyapun teramati tidak terlalu ekonomis seperti yang berasal dari jalur porpiri batuan beku asam.

Unsur logam dasar Zn pada mineral bijih Sfalerit (ZnS) seperti halnya juga $\mathrm{Pb}$ dan $\mathrm{Cu}$ secara primer dihasilkan oleh proses hidrotermal atau kontak metasomatik bersama galena. Proses alterasi selanjutnya adalah oksidasi yang menghasilkan Smitsonit $\left(\mathrm{ZnCO}_{3}\right)$ atau Zinsit (ZnO) yang apabila dalam jumlah besar akan juga sebagai bijih seng.

Kandungan $\mathrm{Zn}$ di daerah telitian nampak sangat fluktuatif dari barat ke timur dengan rata-rata kandungan selalu lebih tinggi dari $\mathrm{Cu}$ dan $\mathrm{Pb}$. Walaupun pada kejadian primernya secara hidrotermal selalu berasosiasi dengan galena namun tidak menunjukkan kurva yang korelatif antara $\mathrm{Zn}$ dan $\mathrm{Pb}$ baik di pantai maupun di lepas pantai. Hal ini berarti pemisahan tersebut terjadi setelah proses oksidasi terhadap masing-masing mineral primer (sfalerit, galena). Kemudian dipisahkan secara gravitasi (gravity setling) dari masingmasing berat jenis yang berbeda, yang mana mineral hasil oksidasi sfalerit lebih ringan daripada hasil oksidasi galena. Pada sedimen lepas pantai pemisahan sebaran barat-timur tersebut diakibatkan oleh perbedaan berat jenis dalam media air lepas pantai. Oleh karena itu dapat pula disimpulkan bahwa peningkatan konsentrasi $\mathrm{Pb}$ dan $\mathrm{Cu}$ akan lebih banyak ke arah daratan.

Logam dasar Emas (Au) dan perak (Ag) pada umumnya saling berasosiasi yang mana masing-masing logam tersebut pada awalnya terjadi secara hidrotermal. Kemudian pada proses selanjutnya khususnya emas cenderung menuju pada kandungan yang lebih murni, yaitu endapan letakan (placer deposit) atau berasosiasi dengan urat-urat kuarsa pada breksi atau konglomerat. Batuan ini di daerah telitian dijumpai pada Formasi Jampang dan Bentang pada aluvium Resen, sehingga dapat diinterpretasikan berasal dari kedua formasi batuan tersebut. Kandungan urat kuarsa yang sangat kecil dikarenakan kandungan batuan primer yang terdapat di Formasi Jampang adalah andesitik sehingga pengayaan urat kuarsanya pun tidak terlalu melimpah dibandingkan yang umumnya terdapat pada batuan asam.

\section{SIMPULAN}

- Sebaran unsur logam dasar sebagai mineral plaser dari barat-ke timur yang nampak fluktuatif dapat diinterpretasikan sebagai akibat dari karakteristik pantai dengan bagian-bagian pantai yang berselingan antara bagian pantai yang mempunyai dan yang tidak mempunyai muara sungai.

- Kandungan logam dasar sebaggai logam dasar di lepas pantai yang relatif tinggi pada lokasi pengambilan contoh disebabkan kedekatannya dengan sumber sedimen yaitu muara sungai dan demikian pula sebaliknya untuk yang berkandungan lebih rendah. Dari darat ke lepas pantai fluktuasi kurva nampak menurun, hal ini membuktikan juga bahwa sumber unsur unsur logam dasar sebagai mineral plaser secara dominan berasal dari darat dengan peran media air lepas pantai dan morfologi dasar lepas pantai sebagai penurun tingkat variasi kurva. 


\section{UCAPAN TERIMA KASIH}

Penulis mengucapkan banyak terima kasih kepada rekan-rekan Kris Budiono, M.Sc., Ir. Asep Faturochman, Ir Yogi Noviadi, Ir. Catur Purwanto, Dan Mira Yosi. Serta Tim Editor, sehingga dapat terbitnya paper ini.

\section{DAFTAR PUSTAKA}

Alzwar, M., 1992, Peta Geologi Lembar Pameungeuk, Jawa Barat, Skala 1:100.000, PPPG, Bandung

Setiady, D. 2001, Laporan Penyelidikan Potensi Mineral Perairan Garut Selatan, Jawa Barat, Laporan intern, PPPGL.

Kamiludin, U. 2004, Laporan Penyelidikan Emas di Perairan Muara Kakap, Kalimantan Barat. Laporan intern PPPGL.

Whitten, D.G.A., Brooks, J.R.V., 1982, The Pinguin Dictionary of Geologi, Pinguin Books Ltd., Harmondsworth, Middlesex, England. 


\section{MAKALAH ILMIAH}

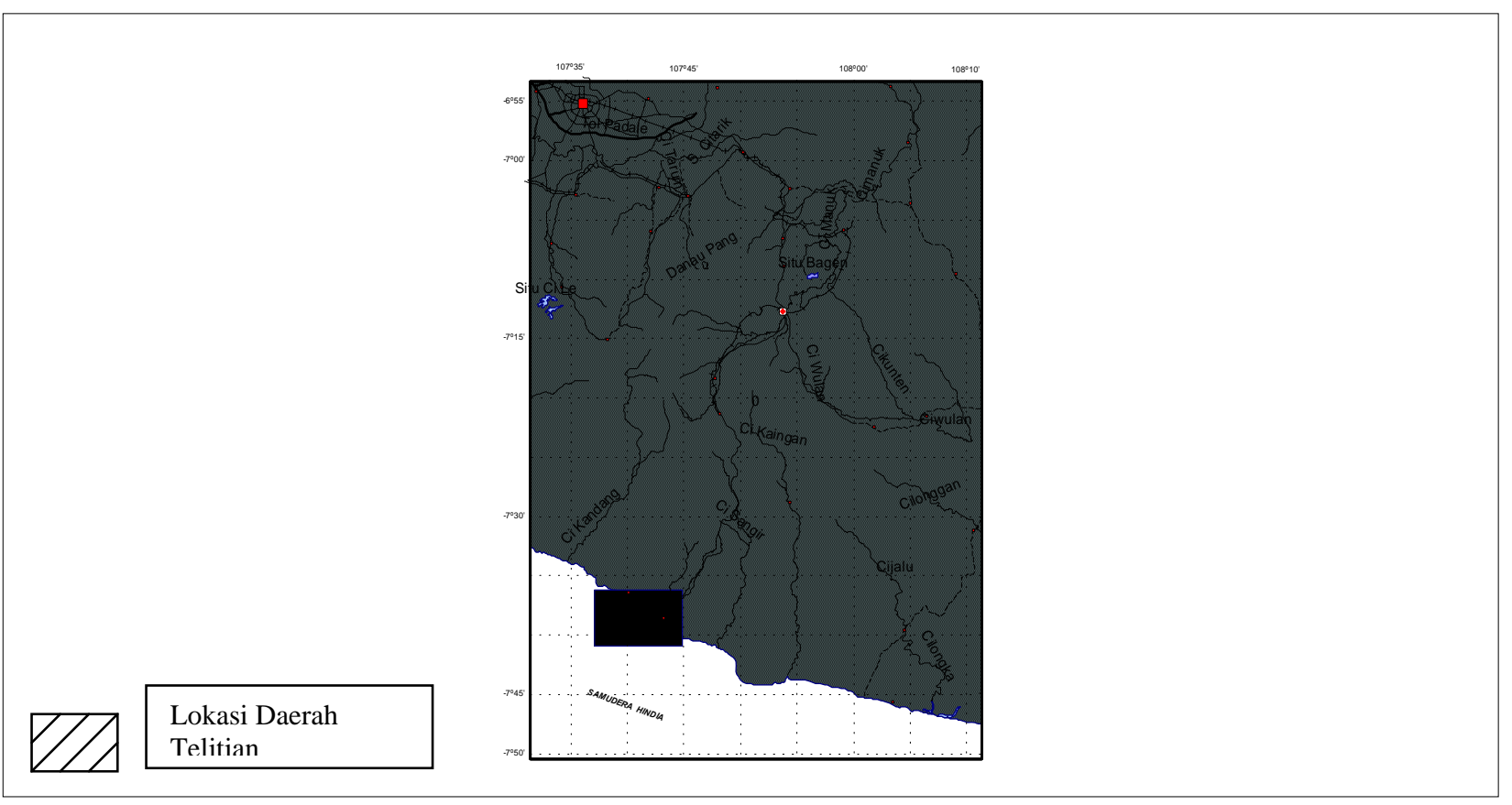

Gambar 1. Peta lokasi daerah telitian

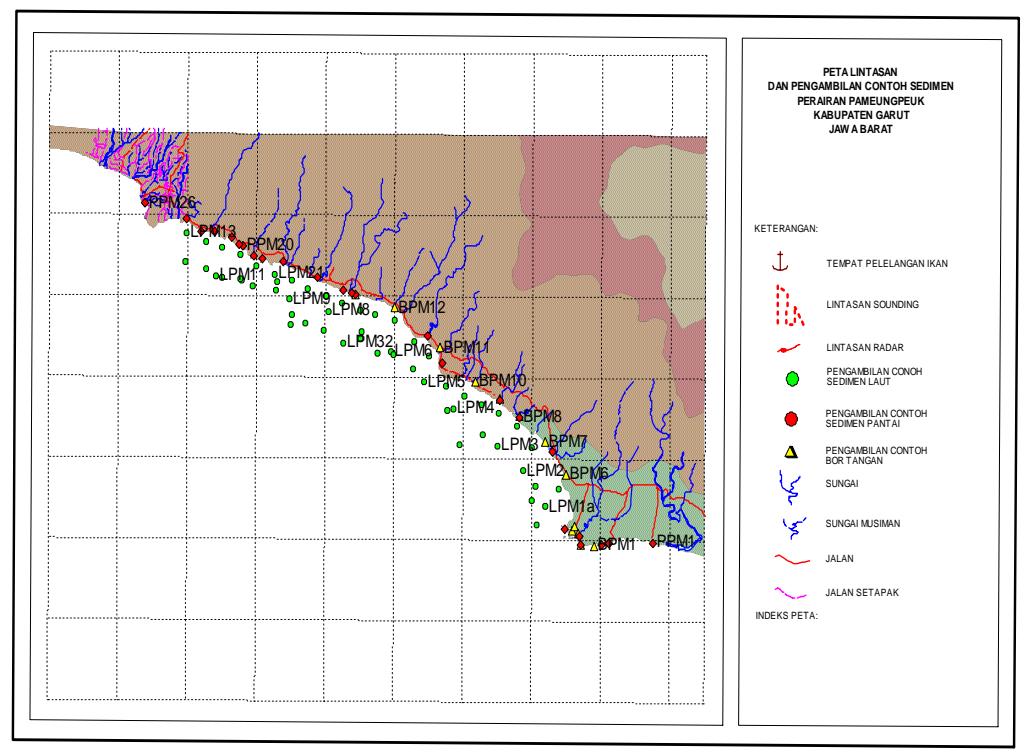

Gambar 2. Peta lokasi pengambilan contoh 


\section{MAKALAH ILMIAH}

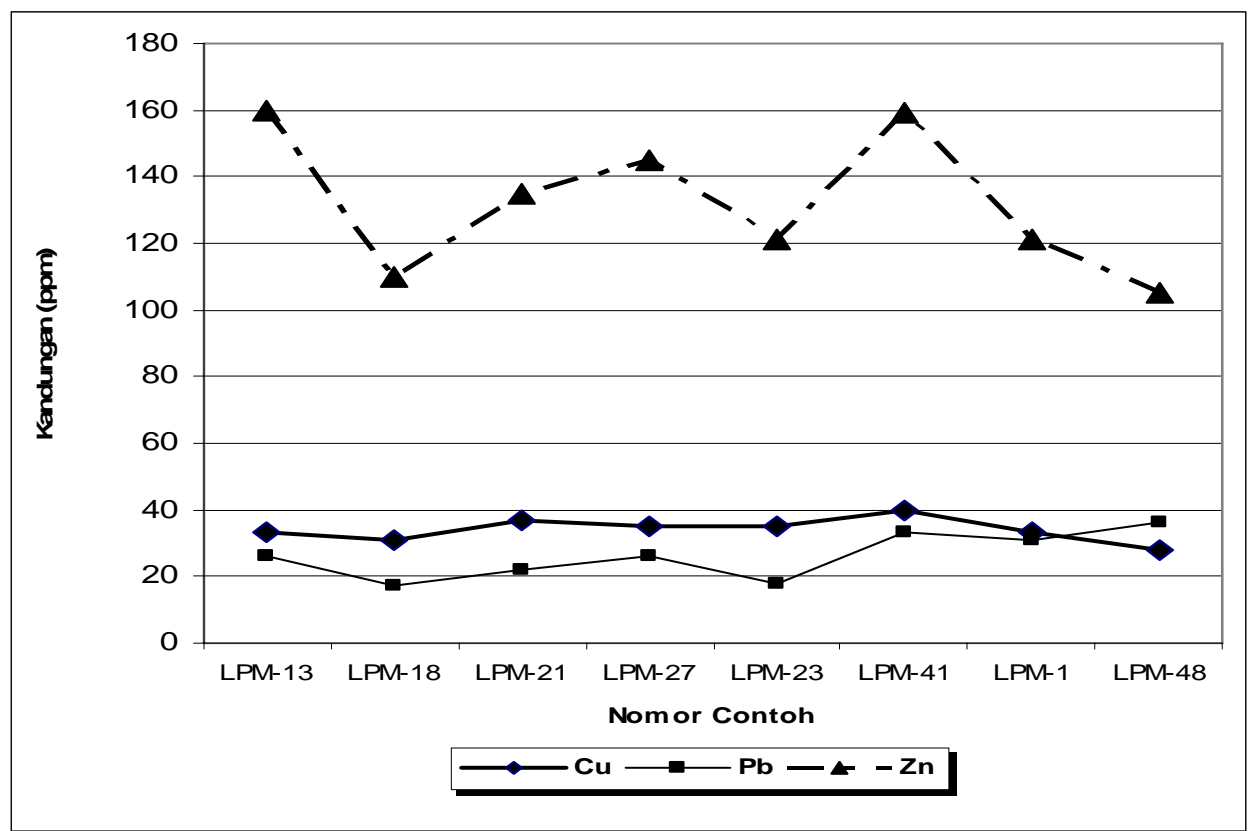

Gambar 3. Kurva Kandungan Tembaga (Cu), Timbal (Pb) dan Seng ( $\mathrm{Zn}$ ) pada Contoh Lepas pantai $\mathrm{cu}, \mathrm{pb}, \mathrm{zn}$

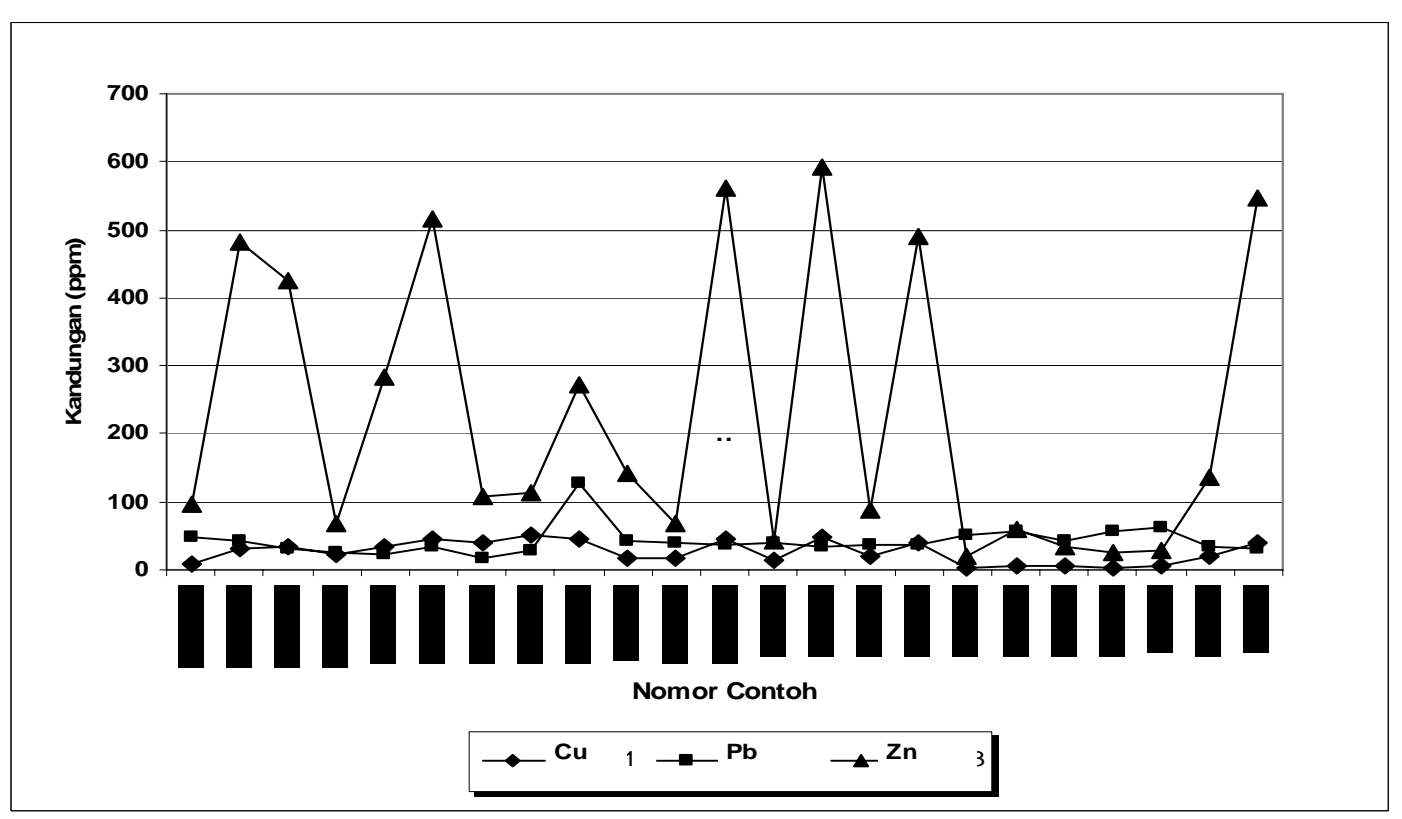

Gambar 4. Kurva Kandungan Tembaga (Cu), Timbal $(\mathrm{Pb})$ dan Seng ( $\mathrm{Zn}$ ) pada Contoh Pantai 


\section{MAKALAH ILMIAH}

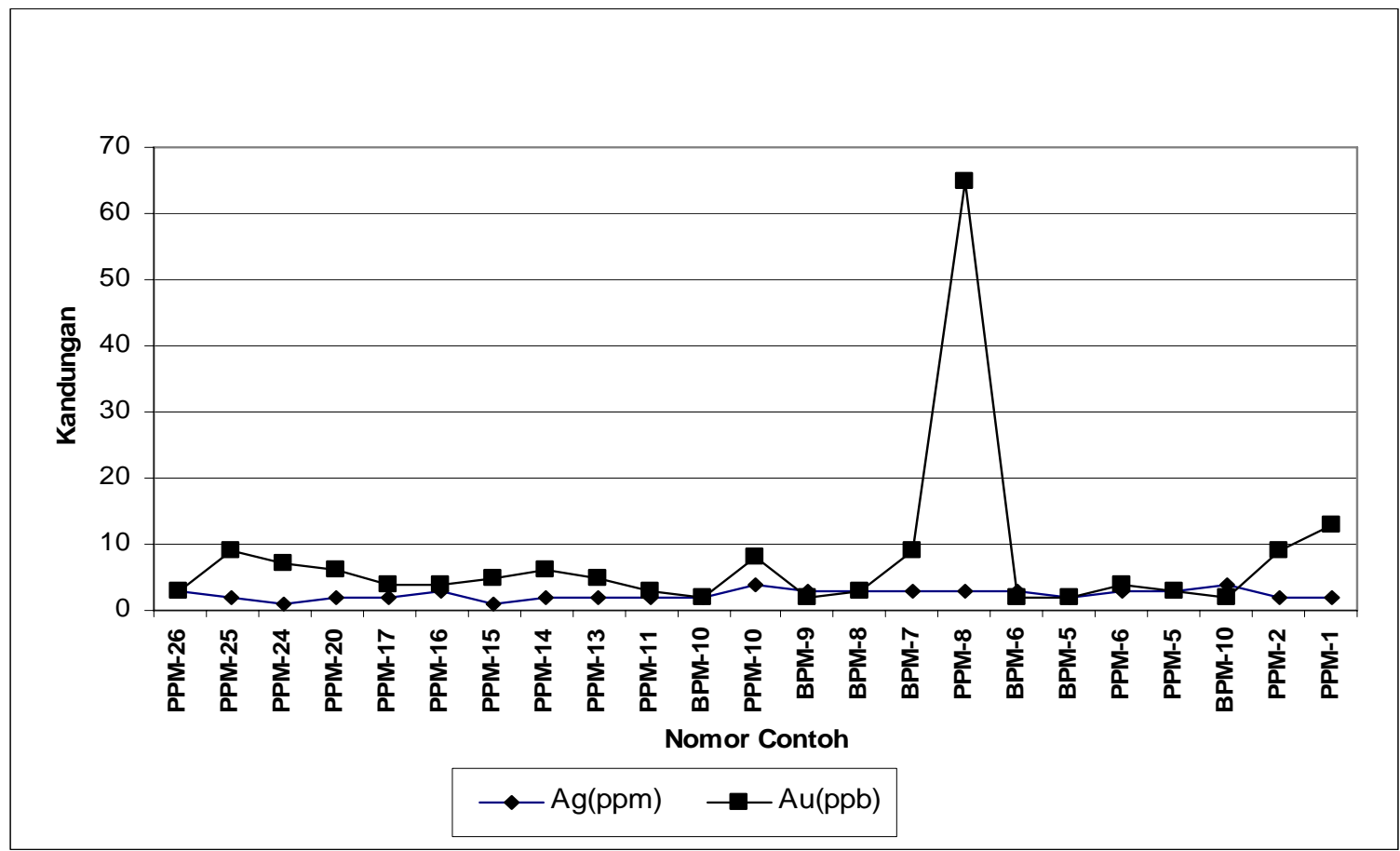

Gambar 5. Kurva Kandungan logam dasar Emas(Au) dan Perak (Ag) pada Contoh Pantai

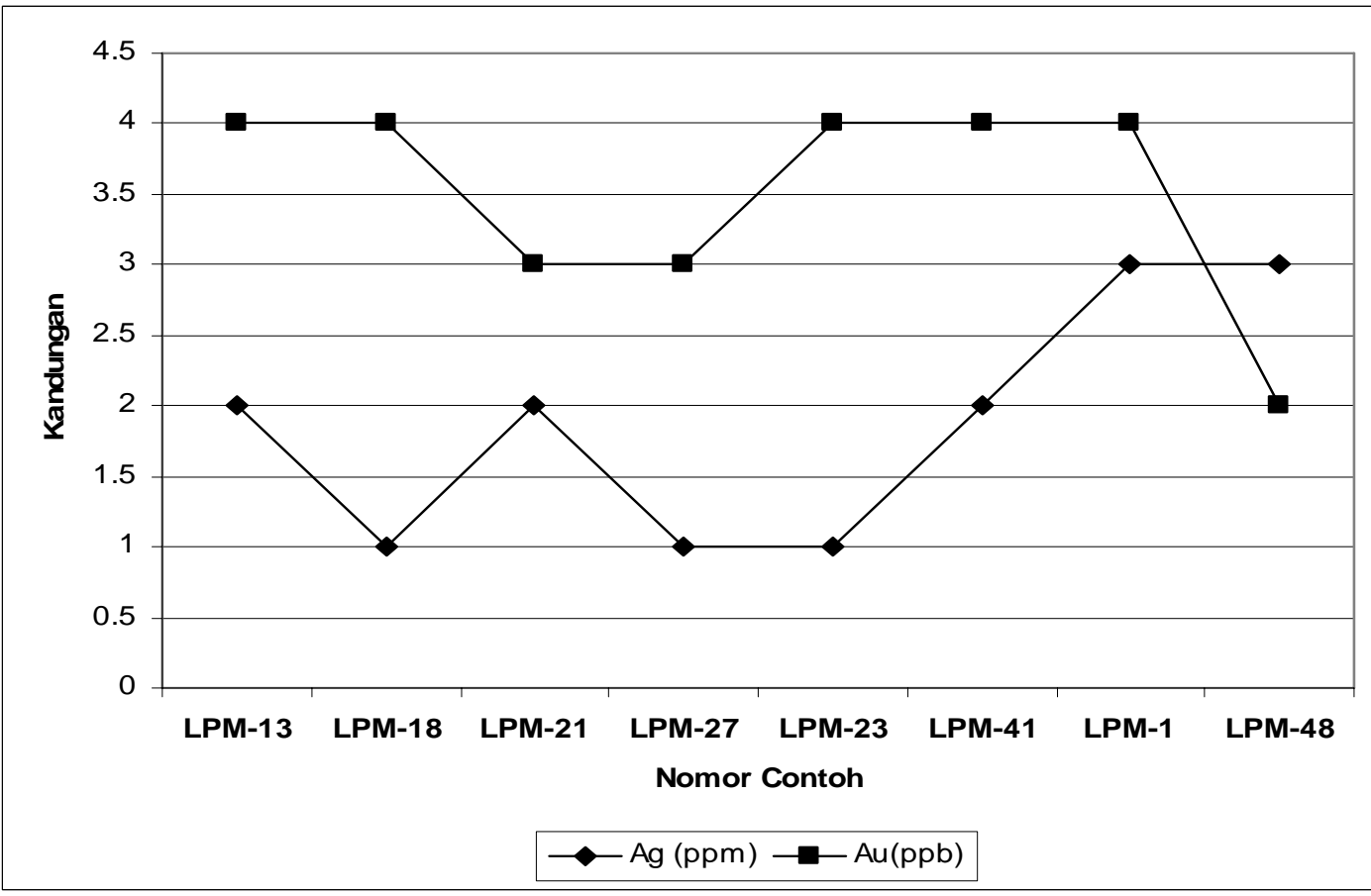

Gambar 6. Kurva Kandungan logam dasar Emas(Au) dan Perak (Ag) pada Contoh Lepas pantai $(\mathrm{Ag}, \mathrm{Au})$ 
Tabel 1. Hasil Analisa Geokimia

\begin{tabular}{|c|c|c|c|c|c|c|}
\hline No.Contoh & $\mathrm{Cu}(p p m)$ & $\mathrm{Pb}(p p m)$ & $\mathrm{Zn}(\mathrm{ppm})$ & PPM & $\mathrm{Ag}(\mathrm{ppm})$ & $A u(p p b)$ \\
\hline PPM-26 & 9 & 48 & 96 & PPM-26 & 3 & 3 \\
\hline PPM-25 & 32 & 43 & 482 & PPM-25 & 2 & 9 \\
\hline PPM-24 & 34 & 31 & 425 & PPM-24 & 1 & 7 \\
\hline PPM-20 & 22 & 26 & 69 & PPM-20 & 2 & 6 \\
\hline PPM-17 & 35 & 22 & 283 & PPM-17 & 2 & 4 \\
\hline PPM-16 & 44 & 35 & 515 & PPM-16 & 3 & 4 \\
\hline PPM-15 & 39 & 18 & 108 & PPM-15 & 1 & 5 \\
\hline PPM-14 & 52 & 27 & 114 & PPM-14 & 2 & 6 \\
\hline PPM-13 & 46 & 128 & 272 & PPM-13 & 2 & 5 \\
\hline PPM-11 & 18 & 42 & 143 & PPM-11 & 2 & 3 \\
\hline BPM-10 & 16 & 39 & 67 & BPM-10 & 2 & 2 \\
\hline PPM-10 & 46 & 36 & 560 & PPM-10 & 4 & 8 \\
\hline BPM-9 & 13 & 39 & 42 & BPM-9 & 3 & 2 \\
\hline BPM-8 & 48 & 34 & 591 & BPM-8 & 3 & 3 \\
\hline BPM-7 & 21 & 37 & 89 & BPM-7 & 3 & 9 \\
\hline PPM-8 & 41 & 36 & 490 & PPM-8 & 3 & 65 \\
\hline ВРМ-6 & 4 & 50 & 21 & ВРМ-6 & 3 & 2 \\
\hline BPM-5 & 7 & 57 & 59 & BPM-5 & 2 & 2 \\
\hline PPM-6 & 5 & 42 & 34 & PPM-6 & 3 & 4 \\
\hline PPM-5 & 4 & 57 & 26 & PPM-5 & 3 & 3 \\
\hline ВPM-10 & 6 & 63 & 27 & BPM-10 & 4 & 2 \\
\hline PPM-2 & 20 & 33 & 137 & PPM-2 & 2 & 9 \\
\hline PPM-1 & 41 & 32 & 546 & PPM-1 & 2 & 13 \\
\hline LPM-13 & 33 & 26 & 160 & LPM-13 & 2 & 4 \\
\hline LPM-18 & 31 & 17 & 110 & LPM-18 & 1 & 4 \\
\hline LPM-21 & 37 & 22 & 135 & LPM-21 & 2 & 3 \\
\hline LPM-27 & 35 & 26 & 145 & LPM-27 & 1 & 3 \\
\hline LPM-23 & 35 & 18 & 121 & LPM-23 & 1 & 4 \\
\hline LPM-41 & 40 & 33 & 159 & LPM-41 & 2 & 4 \\
\hline LPM-1 & 33 & 31 & 121 & LPM-1 & 3 & 4 \\
\hline LPM-48 & 28 & 36 & 105 & LPM-48 & 3 & 2 \\
\hline
\end{tabular}




\section{MAKALAH ILMIAH}

Tabel 2. DESKRIPSI CONTOH PANTAI (Hand speciment)

\begin{tabular}{|c|c|c|c|}
\hline $\begin{array}{l}\text { Nomor } \\
\text { Contoh }\end{array}$ & Koordinat & & DESKRIPSI \\
\hline PPM-01 & 107.479640000 & -7.534930000 & $\begin{array}{l}\text { Pasir besi, hitam sedikit kekuningan, } \\
\text { hls-sdg, mineral hitam melimpah }\end{array}$ \\
\hline PPM-02 & 107.478990000 & -7.528880000 & $\begin{array}{l}\text { Pasir, coklat sedikit keputihan, halus-sedang } \\
\text { lepas, min hitam (30\%), pec. Terumbu } 70 \%\end{array}$ \\
\hline PPM-03 & 107.689420000 & -7.664770000 & $\begin{array}{l}\text { Pasir Terumbu, Coklat keputihan, } \\
\text { uk. Btr. Sedang-kasar, sdk fragmen terumbu }\end{array}$ \\
\hline PPM-04 & 107.690190000 & -7.668270000 & $\begin{array}{l}\text { Pasir, putih kecoklatan, } \\
\text { mgd, pec. Moluska (90\%), magnetit (10\%) }\end{array}$ \\
\hline PPM-05 & 107.700230000 & -7.668480000 & $\begin{array}{l}\text { Pasir, putih kecoklatan, } \\
\text { mgd, pec. Moluska (90\%), magnetit (10\%) }\end{array}$ \\
\hline PPM-06 & 107.703680000 & -7.667810000 & $\begin{array}{l}\text { Pasir, putih sedikit kecoklatan } \\
\text { mgd, pec. Moluska (90\%), magnetit (10\%) }\end{array}$ \\
\hline PPM-07 & 107.506380000 & -7.540230000 & $\begin{array}{l}\text { Pasir, putih kecoklatan, } \\
\text { mgd, pec. Moluska (90\%), magnetit (10\%) }\end{array}$ \\
\hline PPM-08 & 107.512660000 & -7.540490000 & $\begin{array}{l}\text { Pasir besi, hitam sedikit kekuningan, } \\
\text { hls-sdg, mineral hitam melimpah }\end{array}$ \\
\hline PPM-09 & 107.724950000 & -7.667500000 & $\begin{array}{l}\text { Pasir besi, hitam sedikit kekuningan, } \\
\text { sangat halus Gumuk pasir }\end{array}$ \\
\hline PPM-10 & 107.703700000 & -7.667850000 & $\begin{array}{l}\text { Pasir besi, hitam, halus - sedang, lepas } \\
\text { mgd mineral hitam, sdk pec. terumbu }\end{array}$ \\
\hline PPM-11 & 107.660520000 & -7.661620000 & Pasir, coklat sedikit keputihan, halus-sedang \\
\hline PPM-12 & 107.676500000 & -7.630390000 & $\begin{array}{l}\text { lepas, min hitam (60\%), pec. Terumbu } 40 \% \\
\text { Pasir, putih kecoklatan, lepas, hls - sdg } \\
\text { batas dengan pasir hitam, hal - sedg }\end{array}$ \\
\hline PPM-13 & 107.682600000 & -7.661850000 & $\begin{array}{l}\text { Terumbu karang, dengan sedikit pasir pada } \\
\text { bagian atasnya, Coklat sdk keputihan }\end{array}$ \\
\hline PPM-14 & 107.650920000 & -7.608940000 & $\begin{array}{l}\text { Pasir besi, hitam sedikit kekuningan, } \\
\text { hls-sdg, mineral hitam melimpah }\end{array}$ \\
\hline PPM-15 & 107.624000000 & -7.590320000 & $\begin{array}{l}\text { Pasir, coklat tua, halus-sedang } \\
\text { sgt hls-hls, terdapat min. htm, breksi andesit }\end{array}$ \\
\hline PPM-16 & 107.615900000 & -7.582780000 & $\begin{array}{l}\text { Pasir, hitam, lepas, sedang - kasar, } \\
\text { mengandung min.htm (70\%), }\end{array}$ \\
\hline PPM-17 & 107.581130000 & -7.565930000 & $\begin{array}{l}\text { Pasir besi, hitam sedikit kekuningan, } \\
\text { tdp fragmen batuan }\end{array}$ \\
\hline PPM-18 & 107.579200000 & -7.565550000 & $\begin{array}{l}\text { Pasir besi, hitam sedikit kekuningan, } \\
\text { hls-sdg, mineral hitam melimpah }\end{array}$ \\
\hline PPM-19 & 107.575170000 & -7.563930000 & $\begin{array}{l}\text { Pasir besi, hitam, lepas, hls-sdg } \\
\text { mengandung mineral hitam melimpah, }\end{array}$ \\
\hline PPM-20 & 107.546130000 & -7.552860000 & $\begin{array}{l}\text { Pasir, coklat sedikit keputihan, halus-sedang } \\
\text { lepas, min hitam (50\%), pec. Terumbu 50\% }\end{array}$ \\
\hline
\end{tabular}




\begin{tabular}{|l|c|c|l|}
\hline $\begin{array}{c}\text { Nomor } \\
\text { Contoh }\end{array}$ & Koordinat & & \multicolumn{1}{|c|}{ DESKRIPSI } \\
\hline PPM-21 & 107.562540000 & -7.558890000 & $\begin{array}{l}\text { Pasir, hitam sedikit kekuningan, } \\
\text { hls-sdg, mineral hitam melimpah }\end{array}$ \\
\hline PPM-22 & 107.535990000 & -7.551540000 & $\begin{array}{l}\text { Pasir, coklat sedikit keputihan, halus-sedang } \\
\text { lepas, min hitam (60\%), pec. Terumbu 40\% }\end{array}$ \\
\hline PPM-23 & 107.532070000 & -7.550160000 & $\begin{array}{l}\text { Pasir, coklat sedikit keputihan, halus-sedang } \\
\text { lepas, min hitam (60\%), pec. Terumbu 40\% }\end{array}$ \\
\hline PPM-24 & 107.526830000 & -7.546230000 & $\begin{array}{l}\text { Pasir besi, hitam sedikit kekuningan, } \\
\text { hls-sdg, mineral hitam melimpah }\end{array}$ \\
\hline PPM-25 & 107.524850000 & -7.545400000 & $\begin{array}{l}\text { Pasir besi, hitam sedikit kekuningan, } \\
\text { hls-sdg, mineral hitam melimpah }\end{array}$ \\
\hline PPM-26 & 107.521060000 & -7.542650000 & $\begin{array}{l}\text { Pasir, putih kecoklatan, } \\
\text { mgd, pec. Moluska (90\%), magnetit (10\%) }\end{array}$ \\
\hline PPM-27 & & $\begin{array}{l}\text { Pasir, putih kecoklatan, } \\
\text { mgd, pec. Moluska (90\%), magnetit (10\%) }\end{array}$ \\
\hline PPM-28 & & $\begin{array}{l}\text { Pasir, coklat sedikit keputihan, halus-sedang } \\
\text { lepas, min hitam (60\%), pec. Terumbu 40\% }\end{array}$ \\
\hline
\end{tabular}

Tabel 3. Deskripsi, lokasi dan kedalaman percontoh laut

\begin{tabular}{|c|c|c|c|c|}
\hline Nomor & \multicolumn{2}{|c|}{ Koordinat } & $\begin{array}{l}\text { Kedalaman } \\
\text { (M) }\end{array}$ & Litologi \\
\hline LPM1a & 107.672833330 & -7.652666670 & 9.6 & $\begin{array}{l}\text { Pasir, coklat, hls-sdng lepas, min hitam (30\%), pec. } \\
\text { Terumbu } 70 \%\end{array}$ \\
\hline LPM1 & 107.668555560 & -7.644333330 & 26.3 & $\begin{array}{l}\text { Pasir, coklat, hls-sdng lepas, min hitam (30\%), pec. } \\
\text { Terumbu } 70 \%\end{array}$ \\
\hline LPM2 & 107.662277780 & -7.637944440 & 28.0 & $\begin{array}{l}\text { Pasir hitam, hls - sdng, lepas mgd min. hitam, sdk pec. } \\
\text { terumbu }\end{array}$ \\
\hline LPM3 & 107.649666670 & -7.627861110 & 34.0 & $\begin{array}{l}\text { Pasir, coklat, hls-sdng lepas, min hitam (30\%), pec. } \\
\text { Terumbu } 70 \%\end{array}$ \\
\hline LPM4 & 107.628805560 & -7.612666670 & 34.0 & $\begin{array}{l}\text { Pasir, coklat, hls-sdng lepas, min hitam (30\%), pec. } \\
\text { Terumbu } 70 \%\end{array}$ \\
\hline LPM5 & 107.614111110 & -7.601944440 & 41.0 & $\begin{array}{l}\text { Terumbu karang,putih dg sdk pasir pada bagian } \\
\text { atasnya, }\end{array}$ \\
\hline LPM6 & 107.598138890 & -7.589222220 & 43.0 & $\begin{array}{l}\text { Terumbu karang,putih dg sdk pasir pada bagian } \\
\text { atasnya, }\end{array}$ \\
\hline LPM7 & 107.584250000 & -7.581222220 & 15.0 & $\begin{array}{l}\text { Terumbu karang,putih dg sdk pasir pada bagian } \\
\text { atasnya, }\end{array}$ \\
\hline LPM8 & 107.567919000 & -7.572971000 & 18.0 & $\begin{array}{l}\text { Terumbu karang,putih dg sdk pasir pada bagian } \\
\text { atasnya, }\end{array}$ \\
\hline LPM9 & 107.549416670 & -7.568000000 & 26.0 & $\begin{array}{l}\text { Terumbu karang,putih dg sdk pasir pada bagian } \\
\text { atasnya, }\end{array}$ \\
\hline LPM10 & 107.531361110 & -7.562944440 & 33.0 & $\begin{array}{l}\text { Terumbu karang,putih dg sdk pasir pada bagian } \\
\text { atasnya, }\end{array}$ \\
\hline LPM11 & 107.513722220 & -7.558611110 & 42.0 & $\begin{array}{l}\text { Terumbu karang,putih dg sdk pasir pada bagian } \\
\text { atasnya, }\end{array}$ \\
\hline LPM12 & 107.498694440 & -7.553027780 & 32.0 & $\begin{array}{l}\text { Terumbu karang,putih dg sdk pasir pada bagian } \\
\text { atasnya, }\end{array}$ \\
\hline LPM13 & 107.499472220 & -7.541027780 & 12.0 & $\begin{array}{l}\text { Terumbu karang,putih dg sdk pasir pada bagian } \\
\text { atasnya, }\end{array}$ \\
\hline
\end{tabular}


MAKALAH ILMIAH

\begin{tabular}{|c|c|c|c|c|}
\hline Nomor & \multicolumn{2}{|c|}{ Koordinat } & $\begin{array}{l}\text { Kedalaman } \\
\text { (M) }\end{array}$ & Litologi \\
\hline LPM14 & 107.508611110 & -7.544583330 & 9.0 & $\begin{array}{l}\text { Terumbu karang,putih dg sdk pasir pada bagian } \\
\text { atasnya, }\end{array}$ \\
\hline LPM15 & 107.509083330 & -7.555611110 & 39.0 & $\begin{array}{l}\text { Terumbu karang,putih dg sdk pasir pada bagian } \\
\text { atasnya, }\end{array}$ \\
\hline LPM16 & 107.516638890 & -7.559388890 & 41.7 & $\begin{array}{l}\text { Pasir hitam, hls - sdng, lepas mgd min. hitam, sdk pec. } \\
\text { terumbu }\end{array}$ \\
\hline LPM17 & 107.516583330 & -7.546666670 & 11.7 & $\begin{array}{l}\text { Terumbu karang,putih dg sdk pasir pada bagian } \\
\text { atasnya, }\end{array}$ \\
\hline LPM18 & 107.525305560 & -7.549500000 & 8.0 & $\begin{array}{l}\text { Pasir hitam, hls - sdng, lepas mgd min. hitam, sdk pec. } \\
\text { terumbu }\end{array}$ \\
\hline LPM19 & 107.525805560 & -7.560388890 & 31.0 & $\begin{array}{l}\text { Pasir hitam, hls - sdng, lepas mgd min. hitam, sdk pec. } \\
\text { terumbu }\end{array}$ \\
\hline CPM1 & 107.525722220 & -7.559916670 & 30.1 & $\begin{array}{l}\text { Terumbu karang,putih dg sdk pasir pada bagian } \\
\text { atasnya, }\end{array}$ \\
\hline LPM20 & 107.533222220 & -7.554250000 & 9.4 & $\begin{array}{l}\text { Terumbu karang,putih dg sdk pasir pada bagian } \\
\text { atasnya, }\end{array}$ \\
\hline LPM21 & 107.541944440 & -7.557805560 & 10.7 & $\begin{array}{l}\text { Pasir hitam, hls - sdng, lepas mgd min. hitam, sdk pec. } \\
\text { terumbu }\end{array}$ \\
\hline LPM22 & 107.550333330 & -7.560472220 & 11.8 & $\begin{array}{l}\text { Terumbu karang,putih dg sdk pasir pada bagian } \\
\text { atasnya, }\end{array}$ \\
\hline LPM23 & 107.558166670 & -7.563805560 & 13.2 & $\begin{array}{l}\text { Pasir hitam, hls - sdng, lepas mgd min. hitam, sdk pec. } \\
\text { terumbu }\end{array}$ \\
\hline LPM24 & 107.566833330 & -7.566666670 & 10.4 & $\begin{array}{l}\text { Terumbu karang,putih dg sdk pasir pada bagian } \\
\text { atasnya, }\end{array}$ \\
\hline LPM25 & 107.590722220 & -7.574000000 & 12.0 & $\begin{array}{l}\text { Terumbu karang,putih dg sdk pasir pada bagian } \\
\text { atasnya, }\end{array}$ \\
\hline LPM26 & 107.542333330 & -7.564444440 & 25.4 & $\begin{array}{l}\text { Terumbu karang,putih dg sdk pasir pada bagian } \\
\text { atasnya, }\end{array}$ \\
\hline LPM27 & 107.542972220 & -7.560972220 & 17.5 & $\begin{array}{l}\text { Pasir, coklat, hls-sdng lepas, min hitam (30\%), pec. } \\
\text { Terumbu } 70 \%\end{array}$ \\
\hline LPM28 & 107.550055560 & -7.574361110 & 36.9 & $\begin{array}{l}\text { Terumbu karang,putih dg sdk pasir pada bagian } \\
\text { atasnya, }\end{array}$ \\
\hline LPM29 & 107.550055560 & -7.578250000 & 43.0 & $\begin{array}{l}\text { Pasir, coklat, hls-sdng lepas, min hitam (30\%), pec. } \\
\text { Terumbu } 70 \%\end{array}$ \\
\hline LPM30 & 107.556861110 & -7.577972220 & 38.1 & $\begin{array}{l}\text { Pasir, coklat, hls-sdng lepas, min hitam (30\%), pec. } \\
\text { Terumbu } 70 \%\end{array}$ \\
\hline LPM31 & 107.565916670 & -7.580555560 & 35.3 & $\begin{array}{l}\text { Pasir, coklat, hls-sdng lepas, min hitam (30\%), pec. } \\
\text { Terumbu } 70 \%\end{array}$ \\
\hline LPM32 & 107.575250000 & -7.586000000 & 38.2 & $\begin{array}{l}\text { Pasir, coklat, hls-sdng lepas, min hitam (30\%), pec. } \\
\text { Terumbu } 70 \%\end{array}$ \\
\hline LPM33 & 107.574694440 & -7.569472220 & 10.6 & $\begin{array}{l}\text { Terumbu karang,putih dg sdk pasir pada bagian } \\
\text { atasnya, }\end{array}$ \\
\hline LPM34 & 107.583472220 & -7.572277780 & 11.7 & $\begin{array}{l}\text { Pasir hitam, hls - sdng, lepas mgd min. hitam, sdk pec. } \\
\text { terumbu }\end{array}$ \\
\hline LPM35 & 107.583444440 & -7.584333330 & 27.4 & $\begin{array}{l}\text { Terumbu karang,putih dg sdk pasir pada bagian } \\
\text { atasnya, }\end{array}$ \\
\hline LPM36 & 107.591861110 & -7.590000000 & 36.2 & $\begin{array}{l}\text { Pasir, coklat, hls-sdng lepas, min hitam (30\%), pec. } \\
\text { Terumbu } 70 \%\end{array}$ \\
\hline LPM37 & 107.600138890 & -7.576500000 & 8.6 & $\begin{array}{l}\text { Pasir, coklat, hls-sdng lepas, min hitam (30\%), pec. } \\
\text { Terumbu } 70 \%\end{array}$ \\
\hline LPM38 & 107.599750000 & -7.590305560 & 43.5 & $\begin{array}{l}\text { Pasir, coklat, hls-sdng lepas, min hitam (30\%), pec. } \\
\text { Terumbu } 70 \%\end{array}$ \\
\hline LPM39 & 107.609111110 & -7.596416670 & 38.3 & $\begin{array}{l}\text { Terumbu karang,putih dg sdk pasir pada bagian } \\
\text { atasnya, }\end{array}$ \\
\hline
\end{tabular}




\section{MAKALAH ILMIAH}

\begin{tabular}{|c|c|c|c|c|}
\hline Nomor & \multicolumn{2}{|c|}{ Koordinat } & Kedalaman & Litologi \\
\hline LPM40 & 107.609500000 & -7.585222220 & 8.2 & $\begin{array}{l}\text { Terumbu karang,putih dg sdk pasir pada bagian } \\
\text { atasnya, }\end{array}$ \\
\hline LPM41 & 107.616611110 & -7.590972220 & 14.2 & $\begin{array}{l}\text { Pasir hitam, hls - sdng, lepas mgd min. hitam, sdk pec. } \\
\text { terumbu }\end{array}$ \\
\hline LPM42 & 107.625111110 & -7.603138890 & 14.3 & $\begin{array}{l}\text { Pasir hitam, hls - sdng, lepas mgd min. hitam, sdk pec. } \\
\text { terumbu }\end{array}$ \\
\hline LPM43 & 107.633805560 & -7.607250000 & 15.2 & $\begin{array}{l}\text { Terumbu karang,putih dg sdk pasir pada bagian } \\
\text { atasnya, }\end{array}$ \\
\hline LPM44 & 107.642083330 & -7.611250000 & 16.7 & $\begin{array}{l}\text { Terumbu karang,putih dg sdk pasir pada bagian } \\
\text { atasnya, }\end{array}$ \\
\hline LPM45 & 107.650361110 & -7.614361110 & 13.9 & $\begin{array}{l}\text { Terumbu karang,putih dg sdk pasir pada bagian } \\
\text { atasnya, }\end{array}$ \\
\hline LPM46 & 107.659500000 & -7.619944440 & 7.0 & $\begin{array}{l}\text { Terumbu karang,putih dg sdk pasir pada bagian } \\
\text { atasnya, }\end{array}$ \\
\hline LPM47 & 107.669083330 & -7.660361110 & 24.8 & $\begin{array}{l}\text { Terumbu karang,putih dg sdk pasir pada bagian } \\
\text { atasnya, }\end{array}$ \\
\hline LPM48 & 107.679250000 & -7.645500000 & 13.0 & $\begin{array}{l}\text { Pasir, coklat, hls-sdng lepas, min hitam (30\%), pec. } \\
\text { Terumbu } 70 \%\end{array}$ \\
\hline LPM49 & 107.666222220 & -7.628527780 & 14.4 & $\begin{array}{l}\text { Terumbu karang,putih dg sdk pasir pada bagian } \\
\text { atasnya, }\end{array}$ \\
\hline LPM50 & 107.666694440 & -7.650222220 & 36.9 & $\begin{array}{l}\text { Pasir, coklat, hls-sdng lepas, min hitam (30\%), pec. } \\
\text { Terumbu } 70 \%\end{array}$ \\
\hline LPM51 & 107.642666670 & -7.623361110 & 35.7 & $\begin{array}{l}\text { Terumbu karang,putih dg sdk pasir pada bagian } \\
\text { atasnya, }\end{array}$ \\
\hline LPM52 & 107.631305560 & -7.627666670 & 37.4 & $\begin{array}{l}\text { Terumbu karang,putih dg sdk pasir pada bagian } \\
\text { atasnya, }\end{array}$ \\
\hline LPM53 & 107.625750000 & -7.613527780 & 44.2 & $\begin{array}{l}\text { Terumbu karang,putih dg sdk pasir pada bagian } \\
\text { atasnya, }\end{array}$ \\
\hline
\end{tabular}

